\title{
The role of haematological indices in predicting early iron deficiency among pregnant women in an urban area of Sri Lanka
}

Miruna Sudharshani Kalaimani Rabindrakumar ${ }^{1}$, V. Pujitha Wickramasinghe², Lallindra Gooneratne ${ }^{3}$, Carukshi Arambepola ${ }^{4}$, Hemantha Senanayake ${ }^{5}$ and Tharanga Thoradeniya ${ }^{1 *}$ (D)

\begin{abstract}
Background: Early detection and treatment of iron deficiency during pregnancy is crucial for optimum pregnancy outcomes. Anaemia is a late indictor of iron deficiency measured as $\mathrm{Hb}<11 \mathrm{~g} / \mathrm{dL}$, and is widely used as a proxy for iron deficiency. We aimed to evaluate the role of red cell indices as a screening tool for early detection of iron deficiency among pregnant women in an urban area of Sri Lanka.

Method: A cross-sectional study was conducted among 110 apparently healthy pregnant women $\leq 12$ weeks of gestation attending antenatal clinics in Colombo, Sri Lanka. Women already on nutritional supplements were excluded. Full blood count, serum ferritin (SF) and high sensitive C-reactive protein (hs-CRP) assessments were performed. The women with evidence of inflammation as indicated by hs-CRP $>10 \mathrm{mg} / \mathrm{L}$ were excluded $(N=20)$ from data analysis. Anaemia ( $\mathrm{Hb}<11 \mathrm{~g} / \mathrm{dL}$ ) and iron deficiency (SF $<30 \mu \mathrm{g} / \mathrm{L}$ ) were defined according to WHO guidelines. Receiver operating characteristics curves were used to derive red blood cell indices that showed the optimal cut-offs in detecting early iron deficiency.
\end{abstract}

Results: Of the 90 women, 63 (70.0\%) were iron deficient (SF < $30 \mu \mathrm{g} / \mathrm{L}$ ), out of whom 10 (15.9\%) were identified as having iron deficiency anaemia $(\mathrm{Hb}<11 \mathrm{~g} / \mathrm{dL})$. A high sensitivity $(>70 \%)$ in the prediction of iron deficiency was obtained for the optimal cut-off values of $\mathrm{Hb}<12.2 \mathrm{~g} / \mathrm{dL}, \mathrm{MCV}<83.2 \mathrm{fl}, \mathrm{MCH}<26.9 \mathrm{pg}$ and $\mathrm{MCHC} 33.2 \mathrm{~g} / \mathrm{dL}$ while maintaining a specificity $>40 \%$.

Conclusion: Iron deficiency can be predicted in early stages using $\mathrm{Hb}$ and red cell indices, which is much less expensive. This could be a useful method in areas with limited resources and a high prevalence of iron deficiency.

Keywords: Iron deficiency, Haemoglobin, Red cell indices, Pregnancy

\section{Background}

Iron deficiency is the commonest nutritional problem in the world, affecting over two billion people. Iron deficiency anaemia is its main consequence, considered a global public health problem, mostly affecting developing countries. Pregnant women, women of child bearing age and young children are the most vulnerable to develop iron deficiency anaemia. It is a well-recognized

\footnotetext{
* Correspondence: tharanga@bmb.cmb.ac.lk

${ }^{1}$ Department of Biochemistry and Molecular Biology, Faculty of Medicine, University of Colombo, Colombo, Sri Lanka

Full list of author information is available at the end of the article
}

direct and indirect cause of maternal death [1]. Globally, $38 \%$ of pregnant women are affected by anaemia, mostly due to iron deficiency [1-3].

Iron deficiency results when iron stores become depleted due to long-standing negative iron balance. This reduces 'storage iron' such as ferritin and haemosiderin, in turn affecting the normal iron turnover in the body and compromises the supply of iron to the transport protein apotransferrin [4]. This leads to decreased transferrin saturation and increased transferrin receptor availability in the circulation, leaving no more iron to be mobilized if additional iron is required $[4,5]$. If not corrected, it will

(c) The Author(s). 2018 Open Access This article is distributed under the terms of the Creative Commons Attribution 4.0 International License (http://creativecommons.org/licenses/by/4.0/), which permits unrestricted use, distribution, and 
shift to the second stage known as iron deficient erythropoiesis where haemoglobin $(\mathrm{Hb})$ concentration starts to fall due to impaired red blood cell synthesis, resulting in iron deficiency anaemia. Correspondingly, it causes a detectable change in the mean corpuscular haemoglobin $(\mathrm{MCH})$, mean corpuscular haemoglobin concentration $(\mathrm{MCHC})$ and mean corpuscular volume (MCV) $[4,5]$.

Iron deficiency is recognized to lead to adverse pregnancy outcomes such as intra-uterine growth retardation, low birth weight, preterm birth, and perinatal death [6]. Association of iron deficiency with impaired foetal growth, poor cognitive performance and behaviour in infants is well established [7-9]. Recent evidence suggests that iron deficiency during peri-conceptional period and the first trimester could have a profound and long term effect on the brain development of the infant, even at levels of iron deficiency that is not sufficient to cause maternal anaemia [10]. Further, maternal iron deficiency is a risk factor for iron deficiency in infants [11, 12]. Studies in animal models have shown that periconceptional and early life iron deficiency alters dopamine metabolism, myelination and development of the hippocampus with concurrent impairment of brain development [13, 14]. Although some changes are reversible, some early insults of iron deficiency would be permanent $[13,14]$. Therefore, the British guidelines on the management of iron deficiency in pregnancy recommend targeting prevention of early iron deficiency indicated as serum ferritin (SF) $<30 \mu \mathrm{g} / \mathrm{L}$ during first trimester [15-17].

To prevent and control iron deficiency and iron deficiency anaemia and its adverse maternal outcomes, WHO has developed iron deficiency prevention programmes and recommends universal iron replacement [18]. The routine practice in Sri Lankan antenatal clinics is to measure the $\mathrm{Hb}$ concentration of pregnant women at the booking visit and at 28 weeks of gestation $[19,20]$. Women identified with anaemia $(\mathrm{Hb}<11 \mathrm{~g} / \mathrm{dL})$ at booking visit and at 28 weeks are treated with $120 \mathrm{mg}$ of elemental iron daily while others are placed on a supplemental dose of $60 \mathrm{mg}$ of elemental iron throughout pregnancy [18-20].

The gold standard for assessing iron deficiency is bone marrow analysis, which is too invasive as a screening tool in the routine clinical practice [21]. Serum ferritin, serum transferrin and serum iron are good markers to diagnose iron deficiency $[5,15]$ but these too are relatively expensive assays. Compared to these, red cell indices that are a component of the full blood count determined by automated haematology analysers are less invasive, less cumbersome and inexpensive.

Therefore, we aimed to evaluate the validity of each red cell index including $\mathrm{Hb}$ as a screening tool to detect early iron deficiency at an early stage of pregnancy.

\section{Methods \\ Study design}

A cross-sectional study was conducted among 110 apparently healthy pregnant women of $\leq 12$ weeks of gestation attending antenatal clinics of the Medical Officer of Health $(\mathrm{MOH})$ of the Colombo Municipal Council areas from September 2015 to March 2016. Only women whose period of gestation (POG) was verified as being $\leq 12$ weeks by ultrasound scanning were recruited. Women already on nutritional supplements; diagnosed with long standing illness or on medication that are known to interfere with micronutrient metabolism (e.g. antiepileptic drugs such as acetazolamide, carbamazepine and clobazam, Aspirin and Antacids containing Magnesium hydroxide); with a past history of pregnancy-associated complications (e.g. preeclampsia or gestational diabetes mellitus), multiple pregnancy; suspected of having congenital malformations in the fetus and with evidence of infection (identified by c-reactive protein $(\mathrm{CRP})>10 \mathrm{mg} / \mathrm{L}$ [22]; those diagnosed with or having a family history of thalassemia and other haematological disorders were excluded. The sample size was calculated [23] to test the diagnostic accuracy of red cell indices to identify iron deficiency in pregnancy. The assumed areas under the receiver operating characteristic (ROC) curve of red cell indices in the diagnosis of iron deficiency were based on a previous study (Hb: 0.95, MCV: 0.79, MCH: 0.82, MCHC: 0.88, mean red blood cell distribution width (RDW): 0.78 and red blood cells (RBC): 0.69) [24]. Using a given marginal error of 0.1 and $95 \%$ confidence interval [23], the sample size was 84. To compensate for attrition and exclusions due to concurrent infection, $25 \%$ was added and the final sample size was 110 . The study was approved by the Ethics Review Committee, Faculty of Medicine, University of Colombo, Sri Lanka. Approval was obtained from the Colombo Municipal Council and the $\mathrm{MOH}$ at the antenatal clinics and informed written consent was taken from study participants.

\section{Data collection}

An interviewer-administered questionnaire was used to obtain the sociodemographic information of participants. Antenatal records were used to verify the POG, parity, contraceptive method used, and past obstetric history of the participants. Maternal anthropometry was measured using a standard protocol. Weight was recorded to the nearest $0.1 \mathrm{~kg}$ using a weighing scale (Salter, England; 145 BKDR) and height was measured to the nearest 1 $\mathrm{cm}$ using a stadiometer (Seca, UK; 225). Non-fasting peripheral venous blood samples were collected under sterile conditions into EDTA $(1 \mathrm{ml})$ tubes and to tubes without anticoagulant for serum separation. Blood samples were transported to the laboratory in ice, and serum was separated within $3 \mathrm{~h}$ of collection. 


\section{Laboratory analysis}

Measurements of $\mathrm{Hb}, \mathrm{MCV}, \mathrm{MCH}, \mathrm{MCHC}, \mathrm{RDW}, \mathrm{RBC}$ and packed cell volume (PCV) were obtained by haematology analyser; Celltac E-Nihon Kohden Corp, Tokyo from an accredited laboratory. Serum ferritin was measured by Enzyme Linked Immunosorbent Assays (ELISA) using reagent kits (Cat No.160116 \& Diagnostic Automation, Inc., USA). C-reactive protein was measured by sensitive immunoturbidometric assay by Dimension ${ }^{\circ}$ high sensitivity C-reactive protein (hs-CRP) method (Cat No-434 \& Dimension RxL Max, Siemens, USA). Experimental standards were maintained by daily calibration with standard external quality control (QC) material (Cat No. 370 \& Lyphochek immunoassay plus control, Bio RAD, USA) and pooled serum analysis as an internal quality control. The inter-assay coefficient of variance $(\mathrm{CV})$ and intra-assay $\mathrm{CV}$ were used to check the precision and maintained within 3SD of QC values. According to the WHO guidelines, anemia was defined as $\mathrm{Hb}<11 \mathrm{~g} / \mathrm{dl}$ [25]; and iron deficiency as SF $<30 \mu \mathrm{g} / \mathrm{l}[16$, 17]. Out of 110 women, 20 with hs- CRP $>10 \mathrm{mg} / \mathrm{l}$ were considered as harboring an inflammatory state [22] and excluded from the analysis. The remaining 90 women were categorized as having deficient or sufficient iron stores based on the recommended cut-off for serum ferritin $(30 \mu \mathrm{g} / \mathrm{dL})$.

\section{Statistical analysis}

Statistical analysis was performed using statistical software SPSS version 21 (SPSS Inc., Chicago, IL). Onesample Kolmogorov-Smirnov analysis was used to check the normality of the variables. Concentrations of $\mathrm{Hb}$, $\mathrm{MCV}, \mathrm{MCH}, \mathrm{MCHC}, \mathrm{RBC}$ and $\mathrm{PCV}$ were normally distributed. Non-normally distributed data (SF and RDW) were $\log$ transformed and antilogarithms were used to present the relevant data. Descriptive and chi square tests were used to describe the sociodemographic characteristics of the women. Correlations between SF and red cell indices $(\mathrm{Hb}, \mathrm{MCV}, \mathrm{MCH}, \mathrm{MCHC}, \mathrm{RDW}$ and RBC) were examined by Pearson's correlation coefficients. The mean concentration of red cell indices were compared using Student $t$ test between iron deficient $(\mathrm{SF}<30 \mu \mathrm{g} / \mathrm{dL})$ and women with sufficient iron stores (SF $\geq 30 \mu \mathrm{g} / \mathrm{dL}$ ). Statistical significance was set at $p$ value less than 0.05 .

Receiver operating characteristic curves were constructed to identify the optimal cut-off for red cell indices $(\mathrm{Hb}, \mathrm{MCV}, \mathrm{MCH}$ and $\mathrm{MCHC})$ with the most effective measure of sensitivity and specificity in diagnosing iron deficiency during early pregnancy. The red cell indices were compared against the true iron deficiency indicated by $\mathrm{SF}<30 \mu \mathrm{g} / \mathrm{dL}$. Youden's Index was calculated as (sensitivity + specificity) -100 using the ROC curves.

\section{Results}

The mean age was 26.0 years while the mean POG at booking visit was 9 weeks. Approximately $31 \%$ of the women were primigravida. Most of the women (78.8\%) were from low socio-economic status, with a monthly family income of less than USD 294. Nearly, 88\% of women had secondary education and $84 \%$ were unemployed. The general characteristics of these women according to their iron status are shown in Table 1. There were no significant differences in the socio demographic characteristics between iron deficient and iron sufficient women.

Of the 90 women, $13(14.4 \%)$ were anaemic $(\mathrm{Hb}<11$ $\mathrm{g} / \mathrm{dL})$ while $63(70 \%)$ were iron deficient $(\mathrm{SF}<30 \mu \mathrm{g} / \mathrm{L})$ during early pregnancy. Among the 63 iron deficient women 10 had iron deficiency anaemia $(\mathrm{Hb}<11 \mathrm{~g} / \mathrm{dL}$ and $\mathrm{SF}<30 \mu \mathrm{g} / \mathrm{L})$. The remaining 53 women were not anemic $(\mathrm{Hb}>11 \mathrm{~g} / \mathrm{dL})$. The concentrations of $\mathrm{Hb}$, $\mathrm{MCV}, \mathrm{MCH}$ and $\mathrm{MCHC}$ were significantly lower $(P<$ $0.05)$ in the iron deficient than the iron sufficient women (Table 2). A significant positive correlation was observed between SF and $\mathrm{Hb}(r=0.358 ; p=0.001)$, $\operatorname{MCV}(r=0.322 ; p=0.002), \mathrm{MCH}(r=0.333 ; p=0.001)$ and MCHC $(r=0.286 ; p=0.006)$. No significant association was observed between SF and RDW and RBC.

Receiver operating characteristics curves were constructed for red cell indices to identify optimal cut-offs to predict iron deficiency (Fig. 1). Table 3 shows the diagnostic performance of red cell indices with optimal cut-off acquired via ROC curves. Haemoglobin concentration of $<$ $12.2 \mathrm{~g} / \mathrm{dL}$ was found to be an optimal cut-off to detect early iron deficiency providing a sensitivity of 74.1 and $50.8 \%$ specificity. Similarly, $>70 \%$ sensitivity was noted for the optimal cut-offs of $\mathrm{MCV}<83.2 \mathrm{fl}, \mathrm{MCH}<26.9 \mathrm{pg}$ and $\mathrm{MCHC} 33.2 \mathrm{~g} / \mathrm{dL}$ in the prediction of early iron deficiency while maintaining the specificity $>40 \%$.

\section{Discussion}

The present study noted that although only $14 \%$ (13/90) of studied women at early pregnancy are anaemic $(\mathrm{Hb}<$ $11 \mathrm{~g} / \mathrm{dL})$, a significant number of $63 / 90(70 \%)$ are iron deficient as assessed by SF. The percentage of anaemia noted in our study is similar to the values reported in the national nutrition survey in Sri Lanka in 2009 and in other smaller studies conducted in Sri Lanka [26-29].

Serum ferritin measurements provide a reliable indication of early iron deficiency during pregnancy $[15,16]$. A SF concentration $<15 \mu \mathrm{g} / \mathrm{dL}$ indicates depleted iron stores [17] and nearly $46 \%$ of women in the present study had depleted iron stores. Studies conducted in Sri Lanka have shown that $40-50 \%$ of women have depleted iron stores during their reproductive age and are at risk of developing anemia during pregnancy [30, 31]. 
Table 1 General characteristics according to their iron status at $\leq 12$ weeks of gestation

\begin{tabular}{|c|c|c|c|c|}
\hline Characteristics & $\begin{array}{l}\text { All subjects } \\
(N=90)\end{array}$ & $\begin{array}{l}\text { Women with iron deficiency } \\
\mathrm{SF}<30 \mu \mathrm{g} / \mathrm{L} \\
(N=63)^{\mathrm{a}}\end{array}$ & $\begin{array}{l}\text { Women with sufficient iron stores } \\
S F \geq 30 \mu \mathrm{g} / \mathrm{L} \\
(N=27)^{\mathrm{a}}\end{array}$ & $p$-value \\
\hline Age in years (Mean $\pm S D$ & $26 \pm 5$ & $26 \pm 5$ & $26 \pm 5$ & 0.28 \\
\hline POG in weeks (Mean \pm SD) & $9 \pm 2$ & $9 \pm 2$ & $9 \pm 2$ & 0.38 \\
\hline \multicolumn{5}{|l|}{ Gravidity, n (\%) } \\
\hline Prime & $28(31.1)$ & $22(34.9)$ & $06(22.2)$ & \multirow[t]{3}{*}{0.41} \\
\hline One & $34(37.8)$ & $23(36.5)$ & $11(40.7)$ & \\
\hline$\geq$ two & $28(31.1)$ & $18(28.6)$ & $10(37.1)$ & \\
\hline \multicolumn{5}{|l|}{ Ethnicity, n (\%) } \\
\hline Sinhala & $28(31.1)$ & $18(28.6)$ & $10(37.0)$ & \multirow[t]{4}{*}{0.70} \\
\hline Tamil & $27(30.0)$ & $19(30.2)$ & $08(29.6)$ & \\
\hline Moor & $33(36.7)$ & $24(38.1)$ & 09 (33.4) & \\
\hline Other & $02(2.2)$ & $02(3.1)$ & $00(0.0)$ & \\
\hline \multicolumn{5}{|l|}{ Level of education, n (\%) } \\
\hline No schooling & $04(4.4)$ & $02(3.2)$ & $02(7.4)$ & \multirow[t]{5}{*}{0.22} \\
\hline Primary & $04(4.4)$ & $04(6.3)$ & 00 & \\
\hline Secondary & 79 (87.8) & $56(88.9)$ & $23(85.2)$ & \\
\hline Collegiate & $03(3.4)$ & $01(1.6)$ & $02(7.4)$ & \\
\hline Tertiary & 00 & 00 & 00 & \\
\hline \multicolumn{5}{|l|}{ Employment, n (\%) } \\
\hline Unemployed & $76(84.4)$ & $54(85.7)$ & $22(81.5)$ & \multirow[t]{2}{*}{0.21} \\
\hline Employed & $14(15.6)$ & $09(14.3)$ & $05(18.5)$ & \\
\hline \multicolumn{5}{|l|}{ Monthly family income, n (\%) } \\
\hline$<$ USD 294 & $71(78.8)$ & $51(81.0)$ & $20(74.1)$ & \multirow[t]{3}{*}{0.32} \\
\hline$\geq$ USD 294 & $14(15.6)$ & $10(15.9)$ & $04(14.8)$ & \\
\hline Don't know & $05(5.6)$ & $02(3.1)$ & $03(11.1)$ & \\
\hline
\end{tabular}

Abbreviations: SF serum ferritin, $N$ number of pregnant women, $S D$ standard deviation, POG period of gestation, $n$ (\%) number (percentage)

${ }^{a}$ Data on SF concentration available for 90 women after excluding CRP $>10 \mathrm{mg} / \mathrm{L}$

Table 2 Distribution of red cell indices according to the iron status of pregnant women $(N=90)$

\begin{tabular}{|c|c|c|c|}
\hline Red cell indices & $\begin{array}{l}\text { Women with iron deficiency } \\
S F<30 \mu \mathrm{g} / \mathrm{L} \\
N=63 \\
\text { Mean } \pm S D\end{array}$ & $\begin{array}{l}\text { Women with sufficient iron stores } \\
S F \geq 30 \mu \mathrm{g} / \mathrm{L} \\
N=27 \\
\text { Mean } \pm S D\end{array}$ & $p$ value \\
\hline $\mathrm{Hb}(\mathrm{g} / \mathrm{dL})$ & $11.9 \pm 1.1$ & $12.4 \pm 1.0$ & $0.038^{*}$ \\
\hline MCV (fl) & $82.2 \pm 6.6$ & $85.2 \pm 4.8$ & $0.028^{*}$ \\
\hline $\mathrm{MCH}(\mathrm{pg})$ & $26.7 \pm 1.1$ & $28.1 \pm 1.1$ & $0.016^{*}$ \\
\hline $\mathrm{MCHC}(\mathrm{g} / \mathrm{dl})$ & $32.7 \pm 0.9$ & $33.1 \pm 0.7$ & $0.040^{*}$ \\
\hline RDW $(\%)^{a}$ & $12.6 \pm 1.1$ & $12.3 \pm 1.0$ & 0.197 \\
\hline $\mathrm{RBC}\left(\times 10^{9} / \mathrm{L}\right)$ & $4.4 \pm 0.3$ & $4.3 \pm 0.5$ & 0.245 \\
\hline PCV (\%) & $36.4 \pm 2.9$ & $37.2 \pm 3.0$ & 0.218 \\
\hline
\end{tabular}

Abbreviations: $N$ number of pregnant women, $S D$ standard deviation, $H b$ haemoglobin, $M C V$ mean corpuscular volume, $M C H$ mean corpuscular haemoglobin, $M C H C$ mean corpuscular haemoglobin concentration, $R D W$ red blood cell distribution width and $R B C$ red blood cells

"Significantly different $(p<0.05)$

${ }^{\mathrm{a}}$ Geometric mean 


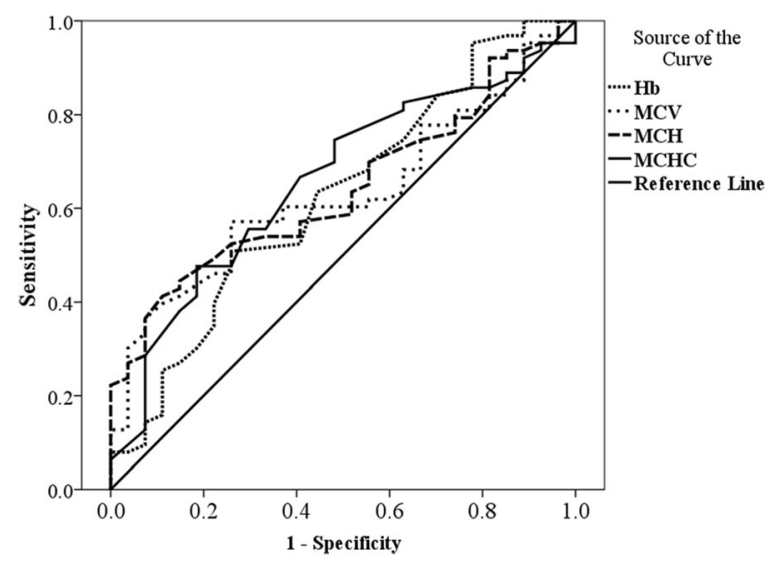

Fig. 1 Receiver operating characteristic curves of red cell indices in the prediction of early iron deficiency in early pregnancy. The ROC curves of $\mathrm{Hb}, \mathrm{MCV}, \mathrm{MCH}$ and $\mathrm{MCHC}$ were compared in the prediction of early iron deficiency indicated by Serum ferritin < $30 \mathrm{\mu g} / \mathrm{dL}$. Abbreviations: $\mathrm{Hb}$ haemoglobin, MCV mean corpuscular volume, MCH mean corpuscular haemoglobin, MCHC mean corpuscular haemoglobin concentration

Importantly, the present study showed that iron deficient women are not captured through routine antenatal care by way of $\mathrm{Hb}$ measurement. The women identified to be anaemic through routine antenatal care $(\mathrm{Hb}<11 \mathrm{~g} / \mathrm{dL})$ were provided with double dose of iron supplementation (120 mg elemental iron per day) and were followed up to monitor the improvement in $\mathrm{Hb}$ levels. Special advice on iron-rich foods and adhering to supplements is also given to these women. The non-anaemic - iron deficient women go undetected and do not receive special care, thus are at high risk of becoming anaemic later in pregnancy. In addition, their infants are at higher risk of developing cognitive impairment and behavioral abnormalities [32].

Low $\mathrm{Hb}$ concentration is not a specific indicator of iron deficiency and studies have highlighted the poor diagnostic performance of $\mathrm{Hb}$ in the prediction of iron deficiency [33, 34]. Considering the magnitude of the problem the current study is a preliminary effort to determine the role of red cell indices in screening for iron deficiency in Sri Lankan pregnant women. Van den Broek et al., [16] have shown that the cut-off point of $30 \mu \mathrm{g} / \mathrm{L}$ of SF concentration is a better indicator of low iron stores in pregnant women following validation with gold standard assessment of bone marrow iron content.
World Health Organization (WHO) guidelines recommend the same cut off $(<30 \mu \mathrm{g} / \mathrm{L})$ to detect iron deficiency in populations with chronic inflammation such as in population with malaria and other infections. [17]. Moreover, the recent British guidelines [15] indicates that the treatment should start when the SF concentration is $<30 \mu \mathrm{g} / \mathrm{L}$, even if the woman is non-anaemic as detected by $\mathrm{Hb}$. Therefore, the current study used SF $30 \mu \mathrm{g} / \mathrm{L}$ as a gold standard to define early stage of iron deficiency. Although the British guideline mentions serum ferritin as a screening tool, it recommends using it on targeted populations rather than universally, considering the time and its cost effectiveness [15]. In a resource-poor setting like Sri Lanka a simple cost effective surrogate for serum ferritin would be of greater value.

The ROC curves were constructed to identify optimal cut-off values for red cell indices to detect iron deficiency in early pregnancy. Most of the countries supplement pregnant women with iron based on the $\mathrm{Hb}$ concentration and assume that they are iron deficient. It is necessary and crucial to correctly identify the truly iron deficient women who have normal $\mathrm{Hb}$ values. Therefore, our goal was to achieve a high sensitivity while maintaining an effective specificity.

Table 3 Diagnostic performance of red cell indices in the prediction of iron deficiency at early pregnancy

\begin{tabular}{llllll}
\hline Red cell Indices & Area under the ROC curve & $p$ value & Optimal cut-off & Sensitivity(\%) & Specificity (\%) \\
\hline $\mathrm{Hb}(\mathrm{g} / \mathrm{dL})$ & 0.625 & 0.062 & 12.2 & 74.1 & 50.8 \\
$\mathrm{MCV}(\mathrm{fl})$ & 0.631 & 0.05 & 83.2 & 74.1 & 57.1 \\
$\mathrm{MCH}(\mathrm{pg})$ & 0.642 & 0.034 & 26.9 & 88.9 & 41.3 \\
$\mathrm{MCHC}(\mathrm{g} / \mathrm{dl})$ & 0.659 & 0.017 & 33.2 & 74.6 & 51.9
\end{tabular}

Abbreviations:\% percentage, $\mathrm{Hb}$ haemoglobin, $\mathrm{MCV}$ mean corpuscular volume, $\mathrm{MCH}$ mean corpuscular haemoglobin, $\mathrm{MCHC}$ mean corpuscular haemoglobin concentration 
The $\mathrm{Hb}$ concentration of $12.2 \mathrm{~g} / \mathrm{dL}$ was selected as an optimal cut-off for the detection of iron deficiency in early pregnancy. This value is considerably higher than the WHO recommended cut-off $(\mathrm{Hb}=11 \mathrm{~g} / \mathrm{dL})$ for anaemia in women during early pregnancy [25]. Similarly, a study conducted among Mexican pregnant women demonstrated a $\mathrm{Hb}$ concentration of $11.5 \mathrm{~g} / \mathrm{dL}$ as predictive of iron deficiency during late pregnancy [34]. When considering the other red cell indices, there are no recognized cut-off values for $\mathrm{MCV}, \mathrm{MCH}$ and $\mathrm{MCHC}$ during pregnancy. The present study derived optimal cutoffs for these red cell indices with a high sensitivity (> 70\%) while maintaining a greater than $40 \%$ specificity. A study conducted among Indian women suggested optimal cut-offs for $\mathrm{Hb} ; 9.7 \mathrm{~g} / \mathrm{dL}, \mathrm{MCV} ; 76.1 \mathrm{fl}, \mathrm{MCH} ; 25.05$ $\mathrm{pg}$ and $\mathrm{MCHC} ; 31.35 \mathrm{~g} / \mathrm{dL}$ in predicting iron deficiency anaemia during second and third trimesters [24]. The optimum cut-off derived for MCV in the present study is higher than the cut-off ( $80 \mathrm{fl}$ ) widely used to identify microcytic anaemia which is caused by iron deficiency [35]. This may be due to the increase in MCV during pregnancy [36]. Further, a higher area under the ROC curves were noted for MCHC (0.659) and $\mathrm{MCH}(0.642)$ when compared to $\mathrm{Hb}(0.625)$ and MCV (0.631). Based on the ROC curves the sensitivity of $\mathrm{MCHC}$ and the $\mathrm{MCH}$ were 74.6 and $88.9 \%$ reaching for women with iron deficiency respectively.

\section{Conclusion}

The present study confirms the unsuitability of the recommended cut-off for $\mathrm{Hb}$ as a screening tool for iron deficiency in early pregnancy. The high rates of false negative results preventing iron deficient women from receiving appropriate treatment. The results could be precarious in places with high iron deficiency rates as observed in the present study. Iron deficiency could be predicted using hematological indices that are produced when a full blood count is ordered. This is a much less expensive test that could of great value in areas with limited resources and a high burden. Although this study has given promising results, iron replacement and vigilance on the improvement of serum ferritin and these red cell indices will enhance the clinical interpretations. Further, it may be appropriate to conduct a study on a larger population across different socio economic strata.

\footnotetext{
Abbreviations

CV: Co-efficient of variance; Hb: Haemoglobin; hs-CRP: High sensitivity C-reactive protein; LRMP: Last regular menstrual period; $\mathrm{MCH}$ : Mean corpuscular haemoglobin; MCHC: Mean corpuscular haemoglobin concentration; MCV: Mean corpuscular volume; PCV: Packed cell volume; POA: Period of amenorrhoea; POG: Period of gestation; QC: Quality control; RBC: Red blood cells; RDW: Red blood cell distribution width; ROC: Receiver operating characteristic; SD: Standard deviation; WHO: World Health Organization
}

\section{Acknowledgements}

We thank the contribution of pregnant women who agreed to participate in the study and staffs at antenatal clinics in Colombo Medical Officer of Health $(\mathrm{MOH})$ areas, S.M.T.H. Senevirathne, Department of Paediatrics, University of Colombo for her support during sample collection.

\section{Funding}

National Science Foundation (Grant No- RG/2011/HS/14) in sample collection and analysis. National research council (Grant No; NRC 15-36) supported during manuscript preparation.

\section{Availability of data and materials}

The datasets used and/or analysed during the current study are available from the corresponding author on reasonable request.

\section{Authors' contributions}

MSKR made substantial contributions to conception and design, acquisition of data, lab and statistical analysis and interpretation of data and been involved in original drafting. PW contributed to conception and critically reviewed the manuscript. LG contributed to conception and critically reviewed for important intellectual content. CA finalized the statistical analysis and critically reviewed and edited the manuscript. HS contributed to interpretation of data, critically reviewed for important intellectual content and copy edited the manuscript. $T$ is responsible for the study design, conception and interpretation of data and intensely reviewed for intellectual contents. All authors have given final approval of the version to be published and agreed to be accountable for all aspects of the work in ensuring that questions related to the accuracy or integrity of any part of the work are appropriately investigated and resolved.

\section{Authors' information \\ MSKR (First author); PhD student at Department of Biochemistry and Molecular Biology, Faculty of Medicine, Colombo. Sri Lanka. The submitted paper is a part of research work of ongoing doctoral degree. \\ $\Pi$ (Corresponding Author); Principal supervisor of the study- Senior Lecturer, Dept. of Biochemistry and Molecular Biology, Faculty of Medicine, Colombo. PW; Professor in Paediatrics, Dept. of Paediatric, Faculty of Medicine, Colombo. LG; Senior Lecturer and consultant haematologist, Dept. of Pathology, Faculty of Medicine, Colombo. \\ CA; Senior Lecturer, Dept. of Community Medicine, Faculty of Medicine, Colombo. HS; Chair Professor of Obstetrics and Gynaecology, Dept. of Obstetrics and Gynaecology, Faculty of Medicine, Colombo.}

\section{Ethics approval and consent to participate}

The study was approved by the Ethics Review Committee, Faculty of Medicine, University of Colombo, Sri Lanka (ERC 15-006) and was carried out in accordance with the Declaration of Helsinki. Informed written consent was obtained from participants before including them in to the study.

\section{Consent for publication}

Not applicable.

\section{Competing interests}

The authors declare that they have no competing interests.

\section{Publisher's Note}

Springer Nature remains neutral with regard to jurisdictional claims in published maps and institutional affiliations.

\section{Author details}

'Department of Biochemistry and Molecular Biology, Faculty of Medicine, University of Colombo, Colombo, Sri Lanka. ${ }^{2}$ Department of Paediatrics, Faculty of Medicine, University of Colombo, Colombo, Sri Lanka. ${ }^{3}$ Department of Pathology, Faculty of Medicine, University of Colombo, Colombo, Sri Lanka. ${ }^{4}$ Department of Community Medicine, Faculty of Medicine, University of Colombo, Colombo, Sri Lanka. ${ }^{5}$ Department of Obstetrics and Gynecology, Faculty of Medicine, University of Colombo, Colombo, Sri Lanka. 
Received: 2 March 2018 Accepted: 2 December 2018

Published online: 22 December 2018

\section{References}

1. Brabin BJ, Hakimi M, Pelletier D. An analysis of anemia and pregnancyrelated maternal mortality. J Nutri. 2001;131(suppl 2S-2):604S-15S.

2. Kassebaum NJ, Jasrasaria R, Naghavi M, Wulf SK, Johns N, Lozano R, et al. A systematic analysis of global anemia burden from 1990 to 2010. Blood. 2014;123(suppl 5):615-24.

3. Stevens GA, Finucane MM, De-Regil LM, Paciorek CJ, Flaxman SR, Branca F, et al. Nutrition impact model study group. Global, regional, and national trends in haemoglobin concentration and prevalence of total and severe anaemia in children and pregnant and non-pregnant women for 19952011: a systematic analysis of population-representative data. Lancet Global Health. 2013;1(suppl 1):e16-25.

4. Nutritional anaemias: Tools for effective prevention and control. 2017. http://apps.who.int/iris/bitstream/handle/10665/259425/9789241513067-eng. pdf;jessionid=C068138DB75056F58B794BC6FD9EB82B? sequence $=1$. Accessed 02 Oct 2018

5. Killip S, Bennett JM, Chambers MD. Iron deficiency anemia. Am Fam Physician. 2007;75:671-78.

6. Haider BA, Olofin I, Wang M, Spiegelman D, Ezzati M, Fawzi WW. Anaemia, prenatal iron use, and risk of adverse pregnancy outcomes: systematic review and meta-analysis. Br Med J. 2013:21:346.

7. Congdon EL, Westerlund A, Algarin CR, Peirano PD, Gregas M, Lozoff B, Nelson CA. Iron deficiency in infancy is associated with altered neural correlates of recognition memory at 10 years. J Pediatr. 2012;160(suppl 6):1027-33.

8. Pala E, Erguven M, Guven S, Erdogan M, Balta T. Psychomotor development in children with iron deficiency and iron-deficiency anemia. Food Nutr Bull. 2010:31(suppl 3):431-5.

9. Madan N, Rusia U, Sikka M, Sharma S, Shankar N. Developmental and neurophysiologic deficits in iron deficiency in children. Indian J Pediatrics. 2011;78(suppl 1):58-64

10. Lozoff B. Early iron deficiency has brain and behavior effects consistent with dopaminergic dysfunction. J Nutr. 2011;141(suppl 4):740S-6S.

11. Scholl TO. Maternal iron status: relation to fetal growth, length of gestation, and iron endowment of the neonate. Nutr Rev. 2011;69(suppl 1):S23-9.

12. Shao J, Lou J, Rao R, Georgieff MK, Kaciroti N, Felt BT, et al. Maternal serum ferritin concentration is positively associated with newborn iron stores in women with low ferritin status in late pregnancy. J Nutr. 2012;142(supply 11):2004-9.

13. Lubach $\mathrm{GR}$, Coe CL. Preconception maternal iron status is a risk factor for iron deficiency in infant rhesus monkeys (Macaca mulatta). J Nutr. 2006; 136:2345-9

14. Mudd AT, Fil JE, Knight LC, Lam F, Liang ZP, Dilger RN. Early-life iron deficiency reduces brain iron content and alters brain tissue composition despite iron repletion: A neuroimaging assessment. Nutrients. 2018; 10(suppl 2):135

15. Pavord S, Myers B, Robinson S, Allard S, Strong J, Oppenheimer C. UK guidelines on the management of iron deficiency in pregnancy. $\mathrm{Br} J$ Haematol. 2012:156:588-600.

16. Van den Broek NR, Letsky EA, White SA, Shenkin A. Iron status in pregnant women: which measurements are valid? Br J Haematol. 1998;103:817-24.

17. World Health Organization. Serum ferritin concentrations for the assessment of iron status and iron deficiency in populations. 2011. http://apps.who.int/ iris/bitstream/handle/10665/85843/WHO_NMH_NHD_MNM_11.2_eng.pdf? sequence=1\&isAllowed=y. Accessed 02 Oct 2018.

18. World Health Organization. Guideline: Daily iron and folic acid supplementation in pregnant women. 2012. http://apps.who.int/iris/bitstream/handle/10665/ 77770/9789241501996 eng.pdf;isessionid=EFFD7086562FC315C7F4BC36A5 206EC7? sequence=1. Accessed 12 Sept 2018.

19. Antenatal care General circular - 02-85/2014, Sri Lanka. 2014. http://www. health.gov.Ik/CMS/cmsmoh1/upload/english/02-85-2014-eng.pdf. Accessed 4 June 2018.

20. World Health Organization. WHO recommendations on antenatal care for a positive pregnancy experience. 2016. http://apps.who.int/iris/bitstream/ handle/10665/250796/97892415? sequence=1. Accessed 25 Sept 2018.

21. Gale E, Torrance J, Bothwell T. The quantitative estimation of total iron stores in human bone marrow. J Clin Investigation. 1963:42(suppl 7):1076.
22. World Health Organization. C-reactive protein concentrations as a marker of inflammation or infection for interpreting biomarkers of micronutrient status. 2014. http://apps.who.int/iris/bitstream/handle/10665/133708/WHO_ NMH_NHD_EPG_14.7_eng.pdf?ua=1. Accessed 25 Sep 2018.

23. Tilaki $\mathrm{KH}$. Sample size estimation in diagnostic test studies of biomedical informatics. J Biomed Inform. 2014;48:193-204.

24. Tiwari M, Kotwal CJ, Kotwal A, Mishra MP, Dutta BV, Chopra BS. Correlation of haemoglobin and red cell indices with serum ferritin in Indian women in second and third trimester of pregnancy. Med J Armed Forces India. 2013; 69(suppl 1):31-6.

25. World Health Organization. Haemoglobin concentrations for the diagnosis of anaemia and assessment of severity. 2011. http://apps.who.int/iris/ bitstream/handle/10665/85839/WHO_NMH_NHD_MNM_11.1_eng. pdf? sequence $=3 \&$ isAllowed=y. Accessed 30 Sep 2018.

26. Jayatissa R, Hossaine SM. Nutrition and food security assessment in Sri Lanka 2009. Medical Research Institute, UNICEF and World Food Programme. 2010. https:/documents.wfp.org/stellent/groups/public/documents/ena/wfp245807. pdf?iframe. Accessed 9 Sep 2018.

27. Demographic \& Health Survey 2006/07, Prevalence of anaemia among children and women in Sri Lanka. Department of census and statistics 2009. http://www.statistics.gov.Ik/social/DHS\%20200607\%20FinalReport.pdf. Accessed 9 Sep 2018.

28. Chathurani U, Dharshika I, Galgamuwa D, Wickramasinghe ND, Agampodi TC, Agampodi SB. Anaemia in pregnancy in the district of Anuradhapura, Sri Lanka need for updating prevalence data and screening strategies. Ceylon Med J. 2012:57:3.

29. Senadheera D, Goonewardene M, Mampitiya I. Anaemia and iron deficiency in pregnant women attending an antenatal clinic in a teaching hospital in southern Sri Lanka. Ceylon Med J. 2017;62:3.

30. Thoradeniya T, Wickremasinghe R, Ramanayake R, Atukorala S. Low folic acid status and its association with anaemia in urban adolescent girls and women of childbearing age in Sri Lanka. Br J Nutr. 2006;95:511-6.

31. de Lanerolle-Dias M, de Silva A, Lanerolle P, Arambepola C, Atukorala S. Micronutrient status of female adolescent school dropouts. Ceylon Med J. 2012:57:2

32. Georgieff MK. Long-term brain and behavioral consequences of early iron deficiency. Nutr Rev. 2011:69:43-8.

33. Salvi CC, Braga MC, Batista FM. Diagnostic accuracy of hemoglobin for iron deficiency in pregnancy: disclosing results of a cited clinical trial. Rev Panam Salud Publica. 2014;36:110-6.

34. Jaime-Pérez JC, García-Arellano G, Méndez-Ramírez N, González-Llano Ó, Gómez-Almaguer D. Evaluation of hemoglobin performance in the assessment of iron stores in feto-maternal pairs in a high-risk population: receiver operating characteristic curve analysis. $\mathrm{Br} J$ Hematol Hemotherapy. 2015;37:178-83

35. Blood and bone marrow pathology. $2^{\text {nd }}$ ed. 2011. https://www.sciencedirect. com/topics/medicine-and-dentistry/mean-corpuscular-volume. Accessed 2 Oct 2018

36. Bain BJ. Blood cells: a practical guide. 4th ed. Oxford: Blackwell Publishing; 2009

\section{Ready to submit your research? Choose BMC and benefit from:}

- fast, convenient online submission

- thorough peer review by experienced researchers in your field

- rapid publication on acceptance

- support for research data, including large and complex data types

- gold Open Access which fosters wider collaboration and increased citations

- maximum visibility for your research: over $100 \mathrm{M}$ website views per year

At BMC, research is always in progress.

Learn more biomedcentral.com/submission 